\title{
Emotional Vulnerability of Displaced Children in a Protracted Conflict
}

\author{
Neinunnem Grace K*, Paramita Bhowmick†, Jayakumar C \\ and Sekar K\$
}

\section{Abstract}

Children are the most vulnerable and affected population in areas of protracted armed conflict. Due to internal displacement, deaths, injury, separation from family, and other social and economic disruptions are on the rise. In India, there are limited studies focussing on children in protracted conflict. This study focusses on the state of Manipur and looks into the relationship between the background to displacement and emotional vulnerability and tries to understand the different aspects of emotional vulnerability that children have faced due to the protracted armed conflict.

Keywords: Protracted Conflict, Displacement, Emotional Vulnerability

\section{Introduction}

Around the globe, countries such as Yemen, Syria and Iraq have accounted for over half of the total population of displacement worldwide due to the political violence and conflict (IDMC GRID, 2015). Apart from these countries, Ukraine, Nigeria, Democratic Republic of Congo (DRC), Afghanistan, Colombia, Central African

\footnotetext{
* Department of Psychiatric of Social Work (DPSW), National Institute of Mental Health and Neurosciences (NIMHANS), Bengaluru, India; grace.khaute1@gmail.com

† NIMHANS, Bengaluru, India; paramita.24684@gmail.com

‡ NIMHANS, Bengaluru, India; jaipsy@gmail.com

§ NIMHANS, Bengaluru, India; sekarkasi@gmail.com
} 
Republic and South Sudan have the highest number of the internally displaced population. About 8.6 million people were internally displaced in the year 2015 with about 24,000 being displaced per day. About 4.8 million people alone were from the Middle East. Over the years, the internally displaced population has increased twice as much as that of the population of refugees (IDMC GRID, 2015).

South Asian countries are the worse affected countries of which India is one of them. In the year 2016, 14,196 conflicts and political protests occurred in South and South East Asia where India held the record of the maximum number of protests. This is similar to 2015 where half the violence was reported from India. Thus, there has been an increase in the violence in 2016 when compared to 2015 (ACLED, 2016). Lebanon had the largest number of refugees with 183 refugees per 1000 inhabitants (UNHCR, 2016). Further, it is being estimated that the number of the internally displaced population has markedly increased over the last 5 years and about 40.3 million people were internally displaced due to violence and conflict (IDMC GRID, 2017).

India has been encountering violence and conflict years after year. Jammu \& Kashmir in the north, Chhattisgarh in the centre and several other states such as Nagaland, Manipur, Assam, and Arunachal Pradesh in the east are considered the most conflicted zones of the country. The state of Manipur has been witnessing a protracted conflict since the 1990s with the clashes between the Naga and Kuki leading to thousands of deaths, destructions and internal displacements. These conflicts can be considered more of an intra-ethnic than inter-ethnic conflict due to the vast ethnic diversity (Hussain et al., 2007). Other economic factors like perceived negligence from the state government, increased rate of unemployment due to corruption leading to poverty, bandhs, curfews and economic blockades led to the growth of insurgency and conflict in the state (Bhattacharjee, 2016). These ongoing protracted conflicts continue to affect the lives of thousands of people especially the children. From a study conducted in the Northeastern states, it was found that children are most affected during armed conflicts. As the period from childhood to adulthood is a transition phase where they grow and learn from the 
environment, they are more vulnerable to the complex environment they live in where they see chaos and conflicts every day. This puts them in constant fear and confusion (NERSWN, 2014). Israel Bronstein et al. (2011) conducted a review on the mental health epidemiology of children settling in Western countries. Psychological distress was seen more in children who are refugees. The variables leading to such distress include demographic factors such as age, sex, place of birth, pre and postmigration experiences like living in a refugee camp, loss or separation from parents, injury, abuse and inadequate social support. They also highlighted the importance of addressing mental health issues among children and the need for research in such an area.

\section{Methods}

The study sample consisting of $(n=97)$ children belonging to the age group of 11- 16 years and internally displaced were randomly selected for the study. The data was collected among the three ethnic groups i.e. Kuki, Naga and Meitei in eight villages of three different districts in the state of Manipur. The population framework was based on the records maintained by the local NGOs, Community Level Workers and informal records maintained by the local community village headmen working at the grass root level with the different NGOs. To assess the sociodemographic information, the Participants' Profile Proforma was used. To assess the emotional vulnerability of the children, Psychosocial Vulnerability Checklist was used which includes four subdomains namely traumatic experience and memory, anxious rumination, socio-cultural influence and perceived sense of despair. The study was approved by the Ethics Committee of NIMHANS.

\section{Results}

Table 1 presents the frequencies of the socio-demographic details of the respondents using descriptive statistics such as age, gender, ethnicity and returned/resettled after displacement of the respondents. Children between the age group of 11-13 years constituted the highest $(57.7 \%)$, children between the age group of 
14-16 years constituted half of the respondents (37.1\%) and children in the age group of 17 years and above $(5.2 \%)$ constituted the least. The majority $(50.5 \%)$ were female while male consisted of $(49.5 \%)$. The ethnicity is classified into three different types: the Kuki $(84.5 \%)$ which is the majority, the Naga $(14.4 \%)$ and the least Meitei (1\%) since the data were mainly collected among the Kuki inhabited villages.

It was found that only $(16.5 \%)$ had returned to their original village after displacement while a significant number $(83.5 \%)$ resettled to a different village after the displacement.

Table 1: Socio- demographic characteristics of the respondents

\begin{tabular}{lcc}
\hline Displacement profile & Frequency & Percentage (\%) \\
\hline Gender & 48 & $49.5 \%$ \\
Male & 49 & $50.5 \%$ \\
Female & & \\
Age & 56 & $57.7 \%$ \\
$11-13$ & 36 & $37.1 \%$ \\
$14-16$ & 5 & $5.2 \%$ \\
$17 \&$ above & & \\
Ethnicity & 82 & $84.5 \%$ \\
Kuki & 14 & $14.4 \%$ \\
Naga & 1 & $1.0 \%$ \\
Meitei & 81 & $83.5 \%$ \\
Resettled to a & & \\
different village & 16 & $16.5 \%$ \\
Returned to the & & \\
same village & & \\
\hline
\end{tabular}

Table 2 represents the relationship between the background of socio-demographic details of displacement and emotional vulnerability. Mann Whitney's U test was used to compare the distribution of the gender of the respondents. The result shows that there is a statistical significance among gender in terms of traumatic experience and memory $(p<0.035)$ among the male respondents. 
The Kruskal Wallis test was used to compare the distribution of the age of the respondents. The result shows significance in traumatic experience and memory $(p<0.017)$ and socio-cultural influence $(p<0.033)$ between the age group of $11-13$ years.

The ethnicity of the respondents with the subdomains was compared using the Kruskal Wallis test. The result shows that there is a significant difference in the ethnicity where the respondents belonging to Kuki ethnic group showed more emotional symptoms in traumatic experience and memory $(p<0.000)$, socio-cultural influence $(p<0.036)$, anxious rumination $(p<0.005)$ and perceived sense of despair $(\mathrm{p}<0.038)$.

Mann Whitney's U test was used to compare the distribution of the respondents if they have returned to the same village or resettled to a different village. A significant result was shown in traumatic experience and memory $(p<0.00)$, socio-cultural influence $(p<0.21)$, anxious rumination $(p<0.006)$ and perceived sense of despair $(p<0.095)$. This shows that emotional symptoms were high among those children who have resettled to a different village.

Table 2: Relationship between the background of displacement and emotional vulnerability

\begin{tabular}{|c|c|c|c|c|c|c|c|c|}
\hline $\begin{array}{c}\text { Socio- } \\
\text { demogra } \\
\text { phic }\end{array}$ & \multicolumn{2}{|c|}{$\begin{array}{l}\text { Traumatic } \\
\text { experience } \\
\& \text { memory }\end{array}$} & \multicolumn{2}{|c|}{$\begin{array}{l}\text { Socio- } \\
\text { cultural } \\
\text { influence }\end{array}$} & \multicolumn{2}{|c|}{$\begin{array}{c}\text { Anxious } \\
\text { rumination }\end{array}$} & \multicolumn{2}{|c|}{$\begin{array}{l}\text { Perceived } \\
\text { sense of } \\
\text { despair }\end{array}$} \\
\hline $\mathrm{n}=97$ & $\begin{array}{c}\text { Mean } \\
\text { rank }\end{array}$ & $\begin{array}{c}\mathrm{P} \\
\text { val } \\
\text { ue }\end{array}$ & $\begin{array}{l}\text { Mean } \\
\text { rank }\end{array}$ & $\begin{array}{c}\mathrm{P} \\
\text { val } \\
\text { ue }\end{array}$ & $\begin{array}{c}\text { Mean } \\
\text { rank }\end{array}$ & $\begin{array}{c}\mathrm{P} \\
\text { valu } \\
\mathrm{e}\end{array}$ & $\begin{array}{l}\text { Mean } \\
\text { rank }\end{array}$ & $\begin{array}{c}\mathrm{P} \\
\text { valu } \\
\mathrm{e}\end{array}$ \\
\hline Gender & & & & & & & & \\
\hline Male & 55.05 & .03 & 46.01 & & 45.71 & & 49.53 & \\
\hline $\begin{array}{l}\text { Female } \\
\text { Age }\end{array}$ & 43.07 & 5 & 51.93 & & 52.22 & & 48.48 & \\
\hline $11-13$ & 42.10 & .01 & 44.42 & .03 & 45.47 & & 44.04 & \\
\hline $14-16$ & 59.01 & 7 & 52.36 & 3 & 53.15 & & 56.43 & \\
\hline $\begin{array}{l}17 \& \\
\text { Above } \\
\text { Ethnicity }\end{array}$ & 54.20 & & 76.10 & & 58.60 & & 51.00 & \\
\hline Kuki & 49.37 & .00 & 46.52 & .03 & 39.30 & .005 & 48.74 & .038 \\
\hline Naga & 44.97 & 0 & 46.32 & 6 & 50.12 & & 44.76 & \\
\hline Meitei & 47.15 & & 47.45 & & 46.05 & & 50.00 & \\
\hline
\end{tabular}




\begin{tabular}{lccccccccc}
\hline $\begin{array}{l}\text { Resettled } \\
\text { or } \\
\text { returned }\end{array}$ & 74.22 & & 63.66 & & 66.56 & & 59.50 & \\
$\begin{array}{l}\text { to the } \\
\text { same }\end{array}$ & 44.02 & .00 & 46.10 & .02 & 45.53 & .006 & 46.93 & .095 \\
$\begin{array}{l}\text { village } \\
\text { Yes }\end{array}$ & & 0 & & 1 & & & & \\
No & & & & & & & & \\
\hline
\end{tabular}

\section{Discussion}

The present study aims to assess the emotional vulnerability of children who have been displaced due to the protracted conflict in Manipur. The socio-demographic detail of children displaced due to the protracted conflict was assessed using the Participant's Profile Proforma which includes the socio-demographic details of the respondents such as the age, gender, ethnicity and the current place of stay.

The age group (Table 1) was categorised into three sub-groups such as the age group between 11-13 years, 14-16 years and 17 years and above respectively. Out of the 97 respondents, the majority of the children belonged to $11-13$ years (57.7\%) followed by the children belonging to $14-16$ years (37.1\%). Children belonging to above 17 years represented the least $(5.2 \%)$. Moreover, the age group between 11-16 years was taken as children belonging to this age group are highly vulnerable not only during armed conflict but also while living in a conflicted zone. The reason may be due to their age and physical vulnerabilities (Betancourt, 2013). Children below the age of 16 years are also mostly affected by the armed conflict with an estimation of over 1 billion which is accounted to nearly one-sixth of the population worldwide (UNICEF, 2009). It was also found that in most of the Northeastern states, children were conscripted to militancy at this age (Amone et al., 2014). The result is also consistent with a study which was done in South Darfur which assessed the psychosocial effects of conflict among children aged between 13-17 years. The study revealed that children belonging to the age group of 13-17 years are most vulnerable in armed conflict (Morgos et al., 2008). 
The gender distribution (Table 1) among the respondents reveals that female respondents were slightly higher than that of male respondents (50.5\% and $49.5 \%)$. Further, in all the villages where the data was collected, female children were more in population than male children. Moreover, compared to male children, female children were more vulnerable and often the victims in times of conflict. This is consistent with the study conducted by $\mathrm{Vu}$ et al., (2014) in Kenya and Getanda et al., (2015) in Azerbaijan among the IDP children where female children were found to be more in number as victims of abuses and neglect, both physically and sexually resulting in greater emotional issues.

With regard to the ethnicity (Table 1), it was divided into 3 subgroups, namely Kuki, Naga and Meitei. Among the ethnic groups, Kuki was the most affected in terms of loss of lives, property, discrimination and displacement. Other studies from Manipur, Singh (2011) and Hussain et al. (2007) revealed that the Kuki population was affected more during the ethnic conflict leading to a maximum number of displacements. It was also found that the maximum displaced population happened in the Kuki community since the year 1992 .

The result (Table 1) shows that a significant number $(83.5 \%)$ of respondents' families had resettled to a different village and only $16.5 \%$ had returned to their original village. One of the major reasons for resettling to a newer place is a loss of home, property, and livelihood along with the persistent security threat and hostile environment (Melvil et al 2016). Resettling back to the original village becomes challenging since resources seem to get destroyed for which they prefer resettling in a different village.

In Table 2, the background relationship of the respondents and emotional vulnerability has been compared. The emotional vulnerability has four subdomains namely: traumatic experience and memory, socio-cultural influence, anxious rumination and perceived sense of despair.

In terms of gender, male respondents were found to have higher traumatic experience and memory. This finding is supported by a study (Betancourt et al., 2013) where it was found that male children were more likely to exhibit internalising and externalising 
problems. Significant PTSD was found in the male children that were worsened by the experiences of conflict, the mistreatment in the family after the conflict, death or loss of a family member and social stigma.

The age group of 11-13 years had higher traumatic experiences and memory and showed higher socio-cultural influence. This present study is in line with a study conducted in the Northeastern part of India where it was found that children above the age of 16 years are more vulnerable and usually have collective memories of their parents going through the displacement. As a result, they have traumatic experiences which have been passed to them instilling hatred and bias in their minds towards the other ethnic communities. This, in turn, creates a gap between them to get along with the other ethnic communities (NERSWN, 2014). With respect to ethnicity, the Kuki respondents showed higher emotional symptoms compared to the respondents of other ethnic groups. This study concurs with another study conducted in Manipur (Hussain et al., 2007). It was found that the respondents who have resettled to a different village also had feelings of hatred, resentment, were more likely to distinguish themselves with the other ethnic groups, had more psychological problems such as anxious rumination and a sense of despair. Further, they were more influenced by socio-cultural factors and experienced more trauma and flashbacks. This is because displacement drains the social and economic conditions to such an extent where it becomes difficult for families to have stable lives again. Most of them tend to identify themselves with other ethnic groups and draw a boundary around them as they are usually in constant fear for their future (Das et al., 2016).

\section{Conclusion}

India has been encountering conflicts especially in the Northeastern regions of the country leading to large scale socio-economic and political unrest resulting in displacements. The state of Manipur has also been affected by the ethnic conflict resulting in large scale displacement which has a long-term mental health implication, where limited number studies focussed on psychosocial vulnerabilities of children in protracted conflict. This study 
attempted to assess the emotional vulnerability of children in protracted conflict and revealed that children undergo higher emotional trauma which may have a direct and indirect impact on their development. Persistence of these conditions necessitates structured psychosocial intervention and care from time to time.

\section{References}

Amone-P'Olak, K., Stochl, J., Ovuga, E., Abbott, R., Meiser-Stedman, R., Croudace, T. J., \& Jones, P. B. (2014). Postwar environment and longterm mental health problems in former child soldiers in Northern Uganda: the WAYS study. J Epidemiol Community Health, jech-2013.

Armed Conflict Location and Event Data Project ACLED (2016): Current Trends: Real- time analysis of Asian Political Violence (No.4)

Betancourt, T. S., Newnham, E. A., McBain, R., \& Brennan, R. T. (2013). Post-traumatic stress symptoms among former child soldiers in Sierra Leone: follow-up study. The British Journal of Psychiatry, 203(3), 196202.

Bronstein, I., \& Montgomery, P. (2011). Psychological distress in refugee children: a systematic review. Clinical Child and Family Psychology Review, 14(1), 44-56.

Das, T. K., Haldar, S. K., Gupta, I. D., \& Mitra, S. (2016). Conflict, Displacement, and Inequality of Opportunity

Getanda, E. M., Papadopoulos, C., \& Evans, H. (2015).The mental health, quality of life and life satisfaction of internally displaced persons living in Nakuru County, Kenya. BMC Public Health, 15(1), 755.

Internal Displacement Monitoring Centre (2015): Global Report on Internal Displacement.

Internal Displacement Monitoring Centre (2017): Global Report on Internal Displacement.

Pereira, M., Gupta, A., \& Rodrigues, S. (2016). Growing up in a conflict zone: children surviving conflict in Manipur. Guwahati: North Eastern Social Research Centre.

Hussain, M., \& Phanjoubam, P. (2007). A status report on internal displacement in Assam and Manipur. Mahaparinirban Culcutta Research Group, Calcutta, [Online: web], accessed on 17/11/2012, URL:

Morgos, D., Worden, J. W., \& Gupta, L. (2008). Psychosocial effects of war experiences among displaced children in southern Darfur. OMEGAJournal of Death and Dying, 56(3), 229-253. 
Norwegian Refugee Council. (2015). IDMC. Global Overview 2015. People internally displaced by conflict and violence, 210-39.

Singh, S. (2011). Causality between Total Expenditure on Education and Economic Growth: A Case Study of Haryana. Indian Journal of Economics, 91(364), 1.

United Nations High Commissioner for Refugees (2016): Global trends forced displacement in 2015.

United Nations International Children's Emergency Fund (2009): Machel Study 10- year Strategic Review: Children and conflict in a changing world

Vu, A., Adam, A., Wirtz, A., Pham, K., Rubenstein, L., Glass, N., \& Singh, S. (2014). The prevalence of sexual violence among female refugees in complex humanitarian emergencies: a systematic review and metaanalysis. PLoS currents, 6 . 